\title{
中咽頭側壁癌に対する広範切除・一期的再建術と術後機能
}

$$
\begin{aligned}
& \text { 佐藤 公則・宮嶋 義巳・坂口伸治 - 柏木 彰一 } \\
& \text { 伊藤 信輔 - 平野 実 - 清川 兼輔* . 田井 良明* }
\end{aligned}
$$

\section{Surgical Treatment and Postoperative Function in Advanced Carcinoma of the Lateral Wall of the Oropharynx}

\author{
Kiminori Sato, Toshimi Miyajima, Shinji Sakaguchi, Shoichi Kashiwagi, \\ Shinsuke Ito, Minoru Hirano, Kensuke Kiyokawa and Yoshiaki Tai \\ (School of Medicine, Kurume University)
}

\begin{abstract}
We reviewed the results of 7 cases of advanced carcinoma of the lateral wall of the oropharynx treated by extensive surgery and reconstruction followed by radiotherapy from 1981 to 1990 . 1) Following the 3-year follow-up, the 3-year control rate of primary lesion was $100 \%$ in T2, 50\% in T3 and $75 \%$ in T4 cases. 2) The 3-year control rate of neck metastasis was $100 \%$ overall. 3) Posttherapeutic speech intelligibility was related to the degree of resection. 4) Regarding posttherapeutic swallowing function, all of the patients ate normal food or gruel with or without occasional aspiration. 5) The five-year cumulative survival rate was $43 \%$ overall.
\end{abstract}

Key words : postoperative function, advanced carcinoma, carcinoma of the oropharynx

\section{はじめに}

中咽頭癌の初治療には放射線を主体にした治療が多く の施設で用いられてきた．しかしこれは，放射線治療の 成績が決して優れているのではなく，手術侵襲，手術手 技, 術後の機能障害などの点から手術的治療が行われに くかったことにもよると考えられる.

久留米大学耳鼻咽喉科では中咽頭癌に対して手術と放 射線を組み合わせた治療を主に行ってきた。本論文では， 3 年以上経過例について, 広範切除手術と一期的再建手 術を行った中咽頭側壁癌の治療成績と術後機能を検討す る.

研究対象および方法

対象は1981年から1990年の間に広範切除手術と一期的 再建手術を行った中咽頭側壁癌の初治療例 7 例(表 1 )で
ある. いずれも 3 年以上経過例である.

性別では男性が 6 例，女性が 1 例であった，年齢は51 歳から71歳(平均63歳)であった。

対象症例の TNM 分類 (1978), Srage 分類(1978)を表 1 亿示す. いずれも進展癌であり, T4 が半数以上を占 めていた。な拴例が M0であった.

病理組織は, 全例扁平上皮癌であった. 治療は原発巣に対しては拡大切除手術と一期的再建を 行った。頸部リンパ節に対しては $\mathrm{N}(+)$ 症例に対して は頸部郭清術を, $\mathrm{N}(-)$ に対しては患側の予防的頸部郭 清術を行った. 放射線治療は, 原発巣と頸部に対して術 前照射，あるいは術前・術後照射を行った。

術後の機能に関しては構音機能と嚥下機能の検査を行 った。構音機能は 5 例に対して 25 音節発語明瞭度検査 ${ }^{1)}$ を行った。曣下機能は 6 例に対して咀嚼嚥下機能の 4 段 
表 1 対象

\begin{tabular}{|c|c|c|c|c|c|c|c|}
\hline $\begin{array}{l}\text { 年齢 } \\
\text { 性 }\end{array}$ & $\begin{array}{l}\text { TNM } \\
(1978)\end{array}$ & $\begin{array}{l}\text { Stage } \\
(1978)\end{array}$ & $\begin{array}{l}\text { 下顎 骨 } \\
\text { 正中離断 }\end{array}$ & 再建材料 & 放射線治療 & 原発巣再発 & 転帰 \\
\hline 1.64男 & $\mathrm{T} 4 \mathrm{~N} 2$ & N & + & 遊離腹直筋皮弁 & 術前照射 (30 Gy) & - & 他病死 \\
\hline 2.71女 & T4N2 & N & + & 遊離腹直筋皮弁 & 術前後照射 (60 Gy) & - & 生 \\
\hline 3.71男 & T3N0 & III & + & 大胸筋皮弁 & 術前後照射 (60 Gy) & - & 生 \\
\hline 4.51男 & $\mathrm{T} 2 \mathrm{~N} 1$ & III & + & 大胸筋皮弁 & 術前後照射 (60 Gy) & - & 生 \\
\hline 5.65男 & T4N1 & N & + & 大胸筋皮弁 & 術前照射 (30 Gy) & + & 原発巣死 \\
\hline 6.51男 & T3N1 & III & + & 広背筋皮弁 & 術前後照射 (60 Gy) & + & 原発巣死 \\
\hline 7.69男 & T4N3 & $\mathrm{N}$ & + & DP 皮弁 & 術前照射 (31.5 Gy) & - & 他 病 死 \\
\hline
\end{tabular}

階評価 (1. 普通食, 2 . 粥食 - 軟食, 3 . 流動食, 4 . 胃管栄養) と誤嚥の 4 段階評価 (1 . 誤嚥なし，2．時々 水分で誤嬹あり，固形物では誤與なし， 3 . 時々水分と 固形物で誤曣あり，4．常に誤曣あり)を行った。なお 與下機能は黒岩の論文2)の一部でも報告している.

\section{結 果}

1 ) 原発巣へのアプローチ

側壁癌の全例に対して下顎骨正中を離断して原発巣へ アプローチする方法を行った。このアプローチにより術 野を広く確保できた。

\section{2 ) 再建材料}

3 例に大胸筋皮弁を，2 例に遊離腹直筋皮弁を，1例 に広背筋皮弁を，1例に対して DP 皮弁を用いた。

3）死 因

死亡例は 4 例であった。死因は原発巣死が 2 例であっ た、頸部リンパ節死, 遠隔転移死はなかった。他病死は 2 例であり，その内訳は脳梗塞と肺炎であった。

\section{4 ） $\mathrm{T}$ 分類別の原発巣再発率}

T2の 1 例には原発栄再発はなかった。T3（2 例）の 1 例之 T4 ( 4 例)の 1 例に原発巣再発を認めた. $T$ 分類 と原発巣再発に明らかな関係はなかった。術前照射を行 った 3 例のうち 1 例に, 術前・術後照射を行った 4 例の らち 1 例に原発巣再発を認めた. 放射線照射の方法と原 発巣再発に明らかな関係はなかった。

3 年原発巣非再発率は T2 で $100 \%, \mathrm{~T} 3$ で $50 \%, \mathrm{~T} 4$ で75\%であった。

5 ) 頸部リンパ節制御率

頸部郭清術あるいは患側の予防的頸部郭清術と放射線 治療で，頸部リンパ節は全例制御されていた。すなわち $\mathrm{N}(+)$ 例, $\mathrm{N}(-)$ 例とも 3 年頸部リンパ節制御率は 100 \%であった。

\section{6 ）治療成績}

Kaplan-Meier 法による 5 年累積生存率 ( 3 年以上経過 例)を図 1 に示す.

5 年累積生存率は $43 \%$ であった. 原病死のみによる（他 病死を打ち切り例とする） 5 年累積生存率は $63 \%$ であっ た。

7 ) 術後機能

a ) 構音機能(表 2 )

切除範囲と構音機能の関係をみると側壁から軟口蓋の 正中近くまで ( $\mathrm{a}$ 群)，あるいは正中を越光て切除( $\mathrm{b}$ 群) しても，構音機能は比較的保たれていた $(66 \% ， 52 \%)$. 側壁から軟口蓋の正中を越えて切除しさらに後壁も合併 切除した例 ( $\mathrm{c}$ 群) では, T2 例では構音機能は比較的保 たれていた $(65 \%)$ が，T4 例では構音機能が非常に悪か った $(13 \%)$. 側壁から軟口蓋の正中近くまで切除しさら に舌根と舌を合併切除した例 ( $\mathrm{d}$ 群)では，構音機能が非 常に悪かった $(28 \%)$.

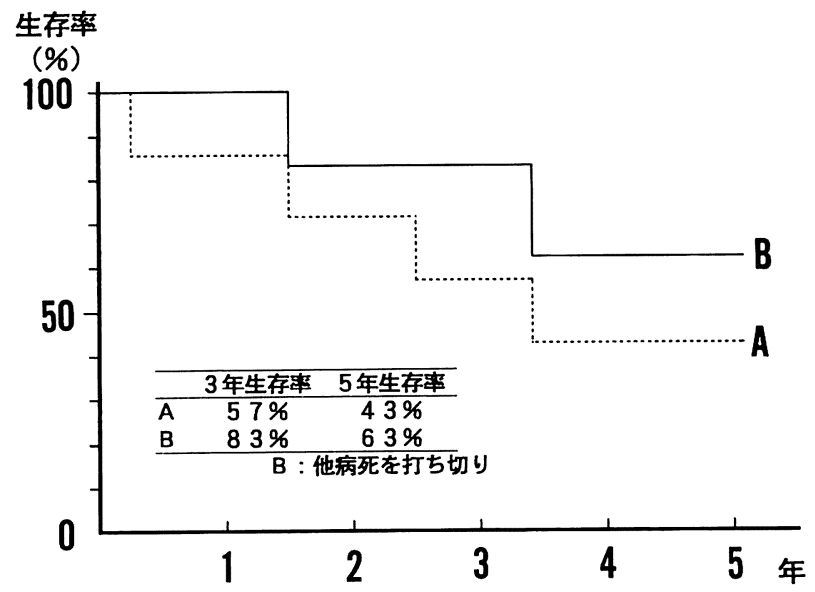

図 1 累積生存率 
表 2 術後の構音機能

\begin{tabular}{cc}
\hline \hline 切除範囲 & 25音節発語明瞭度 \\
\hline $\mathrm{a}$ 群 & $66 \%$ \\
$\mathrm{~b}$ 群 & $52 \%$ \\
$\mathrm{c}$ 群 & $65 \%, \quad 13 \%$ \\
$\mathrm{~d}$ 群 & $28 \%$ \\
$\mathrm{a}$ 群 $:$ 側壁+軟口蓋の正中近く \\
$\mathrm{b}$ 群 : 側壁+軟口蓋の正中以上 \\
$\mathrm{c}$ 群 : 側壁+軟口蓋の正中以上+後壁 \\
\\
$\quad 1 / 2$ 以下 \\
$\mathrm{d}$ 群 : 側壁+軟口蓋の正中近く+舌根 \\
$\quad 2 / 3+$ 舌 $1 / 4$
\end{tabular}

術後の構音機能は切除範囲にある程度相関していた。 再建材料による明らかな差は認められなかった。

b) 嚥下機能(表 3 )

普通食を食べていたのは T2 の 1 例である．側壁から 軟口蓋の $1 / 2$ 以上と後壁の $1 / 2$ 以下を切除 ( $\mathrm{c}$ 群) したが, 普通食を摂取できた。

䋆食・軟食を食べていたのは T3 が 2 例， T4 が 3 例 であった．切除範囲は $\mathrm{a}$ 群が 1 例 (T4), b 群が 2 例( 3 と T4 の各 1 例)， c 群が 1 例 (T4)， d 群が 1 例 (T3) であった。側壁から軟口蓋の $1 / 2$ と舌根 $2 / 3$ と舌 $1 / 4$ を 切除した 1 例 $(\mathrm{d}$ 群)は, 大胸筋皮弁で再建を行ったが鼻 咽腔閉鎖機能不全をきたし最初は流動食しか嚥下できな かった、咽頭弁形成術をさらに行い粥食・軟食を黇下で きるようになった。

側壁癌に広範切除を行っても一期的再建を行えば，粥 食・軟食までは嚥下できるように機能的に保存できた。

誤與が術後になかったのはT3の 1 例であった。軟口 蓋の $1 / 2$ 以上を切除 ( $\mathrm{b}$ 群) したが，術後に誤與はなかっ た.

時々水分で誤燕があったのは, T2が 1 例, T3が 1 例, T4 が 3 例であった. 切除範囲は a 群が 1 例 (T4), $\mathrm{b}$ 群が 1 例 (T4), c 群が 2 例(T2 と T4 の各 1 例), d 群が 1 例 (T3) であった．側壁から軟口蓋の $1 / 2$ と舌根 $2 / 3$ と舌 $1 / 4$ を切除した 1 例 ( d 群) は，大胸筋皮弁で再 建を行ったが鼻咽腔閉鎖機能不全をきたし最初は常に誤 嚥していた．咽頭弁形成術をさらに行い時々水分で誤燕 がある程度に改善できた。

側壁癌に広範切除を行っても一期的再建を行えば，時 々水分で誤與がある程度までに機能的に保存できた。
表 $3 \mathbf{a}$ 術後の咀嚼嚥下機能

\begin{tabular}{lccccc}
\hline \hline & $\mathrm{a}$ 群 & $\mathrm{b}$ 群 & $\mathrm{c}$ 群 & $\mathrm{d}$ 群 & 計 \\
\hline 1. 普通食 & 0 & 0 & 1 & 0 & 1 \\
2. 洣食 ·軟食 & 1 & 2 & 1 & 1 & 5 \\
3. 流動食 & 0 & 0 & 0 & 0 & 0 \\
4. 胃管栄養 & 0 & 0 & 0 & 0 & 0 \\
\hline \multicolumn{1}{c}{ 計 } & 1 & 2 & 2 & 1 & 6
\end{tabular}

表 $3 \mathbf{b}$ 術後の誤醼

\begin{tabular}{|c|c|c|c|c|c|}
\hline & a 群 & $\mathrm{b}$ 群 & $\mathrm{c}$ 群 & $\mathrm{d}$ 群 & 計 \\
\hline 1. 誤曣なし & 0 & 1 & 0 & 0 & 1 \\
\hline $\begin{array}{l}\text { 2. 時々水分で誤曣 } \\
\text { 固形物で誤嚥なし }\end{array}$ & 1 & 1 & 2 & 1 & 5 \\
\hline $\begin{array}{l}\text { 3. 時々水分と固形物で誤 } \\
\text { 與 }\end{array}$ & 0 & 0 & 0 & 0 & 0 \\
\hline 4. 常に誤與 & 0 & 0 & 0 & 0 & 0 \\
\hline 計 & 1 & 2 & 2 & 1 & 6 \\
\hline
\end{tabular}

$\mathrm{a}$ 群 : 側壁十軟口蓋の正中近く

$\mathrm{b}$ 群 : 側壁十軟口蓋の正中以上

c 群 : 側壁十軟口蓋の正中以上十後壁 $1 / 2$ 以下

$\mathrm{d}$ 群 : 側壁十軟口蓋の正中近く+舌根 $2 / 3+$ 舌 $1 / 4$

術後の鱟下機能に関して再建材料による明らかな差は 認められなかった。ただし再建材料により咽頭を狭く形 成した方が與下圧が上がりやすく曣下しやすい傾向があ った。

\section{考察}

先の当教室の検討では，中咽頭癌に対する治療は放射 線照射単独よりも手術と放射線照射を組み合わせた治療 を行らべきであるといら結果を得た ${ }^{31}$ 。とこで1980年代 は中咽頭癌に対しては手術と放射線照射を組み合わせた 治療を基本的に行ってきた。

中咽頭側壁癌の治療は，基本的には $\mathrm{T} 1$ と $\mathrm{T} 2$ に対し てはレーザー切除と放射線照射を組み合わせた機能保存 治療を行い，T3 と T4 の進展癌に対しては広範切除・

一期的再建術と放射線治療を組み合わせた治療を行った。 レーザー切除と放射線照射を併用した中咽頭側壁癌の 機能保存治療の結果は別の論文で報告した4). 本論文で は, 中咽頭(側壁)癌の進展例に対する広範切除と一期的 再建例について治療成績と術後機能を報告した。 


\section{1 ）原発巣制御率}

放射線単独治療に上る中咽頭側壁癌の 3 年原発巣制御 率は, Tong ら5)によれば, T1 で88\%，T2 で67\%，T 3 で $49 \%$ ，T4 で $6 \%$ と報告している。吉田ら6)は放射 線治療による局所制御率は T3 で約 $1 / 3 ， \mathrm{~T} 4$ では制御 された例はなかったと報告している。このように放射線 単独治療で原発巣を制御寸るには限界があり, 特に進展 例では原発巣の制御は困難である. 自験例では広範切除・ 一期的再建術と放射線照射に上る中咽頭側壁癌の 3 年原 発巣非再発率は T2 で100\%，T3 で50\%，T4 で75\%で あった。

中咽頭癌の死因の主なものは原発巣死である6). 今回 の検討でも原病死はすべて原発巣死であった。中咽頭癌 の進展例に対しては広範切除と一期的再建による手術的 治療と放射線照射を組み合わせた治療を行い，原発巣の 制御に努める必要があると考えられた。

2 ) 頸部リンパ節制御率

頸部郭清術あるいは患側の予防的頸部郭清術と放射線 照射で，頸部リンパ節は全例制御されていた。頸部リン パ節に対しても頸部郭清術と放射線照射を組み合わせた 治療が良いといえた。

3 ) 術後機能

広範切除と一期的再建を行った場合，常に問題になる のが術後の構音・嚥下機能障害である。

a ) 構音機能

中咽頭側壁から軟口蓋の正中を越えて切除し再建を行 わないと, 鼻咽腔閉鎖機能不全が強く現れて発語明瞭度 が平均 $21 \%$ と悪くなっていた出が，一期的再建を行うこ とによって軟口蓋の正中を越えて切除しても構音機能が 比較的保たれていた．側壁から軟口蓋の正中を越えて切 除する必要がある例では, 術後の構音機能を保存するた めに再建を行った方が良いといえた. 咽頭後壁, 舌根 (中 咽頭前壁)あるいは舌を合併切除すると，一期的再建を 行っても術後の構音機能は悪かった.

\section{2 ) 與下機能}

中咽頭側壁から軟口蓋の正中を越えて切除し再建を行 わないと鼻咽腔閉鎖機能不全が現れ曣下機能が悪くなっ ていた4)が，一期的再建を行うことによって軟口蓋の正 中を越兄て切除しても临下機能が比較的保たれていた。 軟口蓋の正中を越えて切除が必要な例では，術後の與茄下 機能を保存するために再建を行った方が良いといえた。 中咽頭側壁癌に対して広範切除を行っても一期的再建を
行えば経口摂取は可能で, 術後に粥食・軟食が食べられ， 時々水分で誤與がある程度までに曣下機能を保存できた。 ただし，今回の検討症例では舌根部を広く合併切除した 例がなかったこと，軟口蓋以外に咽頭後壁と舌を合併切 除した例では鼻咽腔閉鎖機能不全をきたし咽頭弁形成術 が必要であったことは留意する必要があると考えられた。

4 ）中咽頭側壁癌に対する治療方針

今回の検討とレーザーを併用する中咽頭側壁癌の機能 保存治療例の検討4) から中咽頭側壁癌に対する治療方針 を考察する.

中咽頭側壁癌の原発巣と頸部リンパ節巣に対する治療 は，手術と放射線照射を併用する治療法が治癒率の点か ら良いと考兄られた．術後の機能障害は切除範囲とある 程度相関して扣り，術後の機能障害を考慮した治療方針 をたてるべきであるといえた．

$\mathrm{T} 1$ と 2 はレーザーを併用する機能保存治療(レー ザー切除単独あるいはレーザーによる減量手術と放射線 療法の併用) 4 )で原発巣はほぼコントロールされて抢り, 術後の燕下機能と構音機能はほぼ満足できた。

T3 ではレーザーを併用する機能保存治療を行っても， 広範切除と一期的再建による手術的治療と放射線照射を 組及合わせた治療を行っても，3 年原発巣非再発率はあ まり変わらなかった．軟口蓋の正中を越えて切除が必要 な例に対しては，術後の構音機能と燕下機能の点から再 建を行った方が良いといえた．何らかの理由で広範切除 と一期的再建ができない例に対しては，レーザー切除と 放射線照射を併用する治療を行っても良いが，この治療 法を行った場合には，連続段階切片標本による切除病変 部の病理組織学的検討を術後に行い，切除範囲が不十分 であれば引き続き広範切除と一期的再建による手術的治 療と放射線照射を組み合わせた治療を行うべきであると いえた。

T4 では中咽頭側壁に隣接した複数の部位を切除する 場合が多く, 術後の機能, 特に構音機能がかなり犠牲に なる．しかし治癒率の点から広範切除と一期的再建によ る手術的治療と放射線照射の併用療法を行らべきである といえた.

\section{まとめ}

1981年から1990年の間に広範切除と一期的再建手術と 放射線照射の併用療法を行った中咽頭側壁癌の初治療例 7 例(いずれも 3 年以上経過例)を検討し以下の結果を得 
た。

1 ）いずれも進展癌であり T4 が半数以上を占めてい た。

2 ） 3 年原発巣制御率は T2 で $100 \%, \mathrm{~T} 3$ で $50 \%, \mathrm{~T}$ 4 で75\%であった.

$3 ） 3$ 年頸部リンパ節制御率は $100 \%$ であった.

4 ）術後の構音機能は, 側壁と軟口蓋の正中を越えて 切除しても再建を行ったために構音機能は比較的保たれ た. 軟口蓋のみではなく咽頭後壁や前壁, 舌を合併切除 すると術後の構音機能は悪かった. 術後の嚥下機能は, 全例経口摂取が可能で, 粥食・軟食を嬹下でき時々䛊與 がある程度までに機能を保存できた。

5 ) Kaplan-Meier 法による 5 年累積生存率 ( 3 年以上 経過例)は43\%であった. 原病死のみによる(他病死を打 ち切り例とする） 5 年累積生存率は63\%であった.

\section{文献}

1 ) 大久保洋, 前田龍男, 上村正行, 他: 舌癌術後の構音検査 一発語明瞭度検査用の 25 音リストの提案一. 日耳鼻 88 : $876 \sim 881,1985$.

2 ) 黒岩泰直：口腔および中咽頭癌術後の曣下機能.耳鼻 38 : 812 824, 1992.

3 ) Matsuo K, Kamimura M, Hirano M, et al : Carcinoma of the mesopharynx ; a retrospective investigation of 43 patients. Kurume Med J 29 Suppl : 87 95, 1982.

4 ）佐藤公則, 宮嶋義巳, 黒岩泰直, 他 : レーザーを併用する 中咽頭側壁癌の機能保存治療. 耳鼻臨床 補 $80: 25 \sim 30$, 1995.

5 ) Tong D, Laramore GE, Griffin TW, et al : Carcinoma of the tonsillar region; results of external irradiation. Cancer $49: 2009 \sim 2014,1982$.

6 ）吉田疸一, 佐々木良二, 前田一, 他 : 中咽頭癌の遠隔成 績. 日癌治 $21: 632 \sim 640,1986$.

$\left(\begin{array}{l}\text { 別刷請求先 : 佐藤公則 } \\ \mathbf{T} 830 \text { 久留米市旭町 } 67 \\ \text { 久留米大学医学部耳鼻咽喉科学教室 }\end{array}\right)$ 